\title{
Legal Education for Women-A Comparison of Practice in China and Turkey
}

\author{
Onur Sabri Durak ${ }^{1,2}$, Yen-Chiang Chang ${ }^{3}$, Nannan Wang ${ }^{4}$, Yue Zhao ${ }^{5}$ \\ ${ }^{1}$ Istanbul Technical University Maritime Faculty, Istanbul, Turkey; \\ ${ }^{2}$ Shanghai Maritime University, Shanghai, China; \\ ${ }^{3}$ School of Law, Shandong University, Jinan, China; \\ ${ }^{4}$ School of Management, Shandong University, Jinan, China; \\ ${ }^{5}$ School of Law, Shandong University, Jinan, China. \\ Email: ycchang@sdu.edu.cn, onursabri@hotmail.com \\ Received November $10^{\text {th }}, 2011$; revised December $12^{\text {th }}, 2011$; accepted December $22^{\text {nd }}, 2011$.
}

\begin{abstract}
The concept of human rights has been altering and expanding since the 20th century. The current development as regards human rights is that it covers the "right of education". Since steps are being taken to improve women's fundamental rights, the "right of education", is one of the leading matters to be considered in order to avoid any kind of discrimination against women in the modern world. Unfortunately, as opposed to the theoretical equality of women with men in legal texts, the broader sense of women's rights has been altering and expanding more slowly than in legal texts and the reality differs from the theoretical ideal. This is proven by the fact that there are 960 million adult illiterate all over the world, and among which 2/3 are female. In 2004, there are 121 million children out of school around the world and among which 65 million are girls. The purpose of this article is to indicate and evaluate the legal basis of education in general and legal education in universities and institutions in China and in Turkey, with special attention being paid to Taiwan region, from a historical and comparative perspective. Women, as lawmakers and a part of law enforcement, together with their rights, in particular, the "right of education" and briefly, legal education for women, are all discussed. International Covenants and national legislation which provide fundamental rights on education for women are addressed and obstacles to women's legal education are also addressed.
\end{abstract}

Keywords: Right of Education, Legal Education, Women's Rights

\section{Introduction}

The right to an education has been designated as a fundamental right under international human rights documents. Historically, human rights solely referred to the right to life, liberty and not being subjected to torture or to cruel, inhuman or degrading treatment. Since the Second World War, the concept of human rights has altered and expanded. "The right of education" has now become a fundamental right in the context of human rights. Designation of "the right of education" under international human rights documents has particular two aims:

- To avoid illiteracy;

- To promote education for everyone, without any discrimination and to achieve elementary education for everyone.

${ }^{1}$ UDHR Article 1: "All human beings are born free and equal in dignity and rights. They are endowed with reason and conscience and should act towards one another in a spirit of brotherhood".

${ }^{2}$ UDHR Article 26: "1) everyone has the right to education. Education shall be free, at least in the elementary and fundamental stages. Elementary education shall be compulsory. Technical and professional education shall be made generally available and higher education shall be equally accessible to all on the basis of merit; 2) education shall be directed to the full development of the human personality and to the strengthening of respect for human rights and fundamental freedoms. It shall promote understanding, tolerance and friendship among all nations, racial or religious groups, and shall further the activities of the United Nations for the maintenance of peace; 3) parents have a prior right to choose the kind of education that shall be given to their children". ${ }^{3}$ On 17th October 1999, China notified the Director-General of UNESCO that the Convention will continue to apply to the Macao Special Administrative Region of the People's Republic of China, with effect from 20th December 1999; Turkey has not yet signed the Convention.
In this context, the United Nations (UN) promulgated international human rights documents covering, "the right of education" and promotes education for everyone. One of the signifycant issues which the international human rights documents touch upon is the "education of women" and "women's education right". At the present, there are 960 million adult illiterate all over the world, and among which 2/3 are female. In 2004, there are 121 million children out of school around the world and among which 65 million are girls (Huang, 2006). With regard to these considerations, the UN has promulgated conventions and while some of these conventions solely related to women's rights, some other rights related to women's rights are prescribed in general terms under the international human rights documents, such as:

- The Universal Declaration of Human Rights (UDHR), Article $1^{1}$ and Article $26^{2}$;

- Convention against Discrimination in Education $(\mathrm{CDE})^{3}$, Article $1^{4}$ and consecutive articles therein;

- International Covenant on Economic, Social and Cultural

${ }^{4} \mathrm{CDE}$ Article 1: "1. For the purpose of this Convention, the term "discrimination" includes any distinction, exclusion, limitation or preference which, being based on race, color, sex, language, religion, political or other opinion, national or social origin, economic condition or birth, has the purpose or effect of nullifying or impairing equality of treatment in education and in particular 1) of depriving any person or group of persons of access to education of any type or at any level; 2) of limiting any person or group of persons to education of an inferior standard; 3) subject to the provisions of Article 2 of this Convention, of establishing or maintaining separate educational systems or institutions for persons or groups of persons; or 4) of inflicting on any person or group of persons conditions which are incompatible with the dignity of man". 
Rights (CESCR) $)^{5}$, Article $13^{6}$;

- Convention on the Elimination of All Forms of Discrimination against Women (CEDAW $)^{7}$, Article $1^{8}$, Article $3^{9}$ and Article $10^{10}$

Afore cited international human rights documents generally aim to achieve equal rights for everyone around the world, without any discrimination and specifically aim to achieve fundamental education for all people. Parties to those conventions undertake the responsibility of establishing and maintaining appropriate educational systems for every citizen in their countries.

For this study, we particularly focus on the legal basis of education in mainland China, Taiwan region and Turkey. The main reason for selecting China and Turkey as the object of comparison is that both States share the similar legal system, same legal problems regarding women's legal education might occur within both States. On the other hand, China has experienced rapid growth in terms of economic and legal development. Turkey, as a developing country, has a lot in common in comparison with China. It is, therefore, noteworthy to compare the issues of women's legal education based on similar economic and legal background. The current development in Taiwan region, however, will provide a broad picture as to how

${ }^{5}$ China signed the Covenant on 27th October 1997 and ratified on 27th March 2001; Turkey signed the Covenant on 15th August 2000 and ratified on 23rd September 2003.

${ }^{6}$ ICESCR Article 13: “1) The States Parties to the present Covenant recognize the right of everyone to education. They agree that education shall be directed to the full development of the human personality and the sense of its dignity, and shall strengthen the respect for human rights and fundamental freedoms. They further agree that education shall enable all persons to participate effectively in a free society, promote understanding, tolerance and friendship among all nations and all racial, ethnic or religious groups, and further the activities of the United Nations for the maintenance of peace. 2) The States Parties to the present Covenant recognize that, with a view to achieving the full realization of this right: a) primary education shall be compulsory and available free to all; b) secondary education in its different forms, including technical and vocational secondary education, shall be made generally available and accessible to all by every appropriate means, and in particular by the progressive introduction of free education; c) higher education shall be made equally accessible to all, on the basis of capacity, by every appropriate means, and in particular by the progressive introduction of free education; d) fundamental education shall be encouraged or intensified as far as possible for those persons who have not received or completed the whole period of their primary education; e) the development of a system of schools at all levels shall be actively pursued, an adequate fellowship system shall be established, and the material conditions of teaching staff shall be continuously improved. 3) The States Parties to the present Covenant undertake to have respect for the liberty of parents and, when applicable, legal guardians to choose for their children schools, other than those established by the public authorities, which conform to such minimum educational standards as may be laid down or approved by the State and to ensure the religious and moral education of their children in conformity with their own convictions. 4) No part of this article shall be construed so as to interfere with the liberty of individuals and bodies to establish and direct educational institutions, subject always to the observance of the principles set forth in paragraph I of this article and to the requirement that the education given in such institutions shall conform to such minimum standards as may be laid down by the State”. ${ }^{7}$ China signed the Convention on 17th July 1980 and ratified it on 4th November 1980; Turkey accessed the Convention on 20th December 1985.

${ }^{8}$ CEDAW Article 1: "For the purposes of the present Convention, the term 'discrimination against women' shall mean any distinction, exclusion or restriction made on the basis of sex which has the effect or purpose of impairing or nullifying the recognition, enjoyment or exercise by women, irrespective of their marital status, on a basis of equality of men and women, of human rights and fundamental freedoms in the political, economic, social, cultural, civil or any other field".

${ }^{9} \mathrm{CEDAW}$ Article 3: "States Parties shall take in all fields, in particular in the political, social, economic and cultural fields, all appropriate measures, including legislation, to ensure the full development and advancement of women for the purpose of guaranteeing them the exercise and enjoyment of human rights and fundamental freedoms on a basis of equality with men”.
China and Turkey will look like in the future. We then try to address legal education and the place of women in legal education, in mainland China, Taiwan region and Turkey. While we try to achieve a comparative study, we acknowledge some difficulties experienced during the research and also some differences between the subjected States and Special Administration Region. Such difficulties as indicated above include:

- Membership status of States to international human rights documents is different. In this respect, national legislation is also different for the legal basis of education and right to education;

- Population differences between subject matter States ${ }^{11}$ or region;

- Cultural, social and economic background ${ }^{12}$;

- Differences between educational systems, university entrance systems and in particular, differences in admission to the legal system after higher education ${ }^{13}$;

- Available statistics on education are significantly dated and inadequate for both States and the Special Administration Region. Secondly, the statistics do not provide sufficient information on legal education and beside this, existing statistics are not available for comparison purposes.

Beside the differences specific to the subject matter among States and Special Administration Region, there are several general similarities, such as:

- The significant role of both States and region in education policy and governance;

- The significant percentage of State schools, compared to private schools and institutions;

- Problems existing, particularly for elementary school and for further steps of education.

\footnotetext{
${ }^{10}$ CEDAW Article 10: "States Parties shall take all appropriate measures to eliminate discrimination against women in order to ensure to them equal rights with men in the field of education and in particular to ensure, on a basis of equality of men and women: 1) the same conditions for career and vocational guidance, for access to studies and for the achievement of diplomas in educational establishments of all categories in rural as well as in urban areas; this equality shall be ensured in pre-school, general, technical, professional and higher technical education, as well as in all types of vocational training; 2 ) access to the same curricula, the same examinations, teaching staff with qualifications of the same standard and school premises and equipment of the same quality; 3) the elimination of any stereotyped concept of the roles of men and women at all levels and in all forms of education by encouraging coeducation and other types of education which will help to achieve this aim and, in particular, by the revision of textbooks and school programmes and the adaptation of teaching methods; 4) the same opportunities to benefit from scholarships and other study grants; 5) the same opportunities for access to programmes of continuing education, including adult and functional literacy programmes, particulary those aimed at reducing, at the earliest possible time any gap in education existing between men and women; 6) the reduction of female student drop-out rates and the organization of programmes for girls and women who have left school prematurely; 7) the same Opportunities to participate actively in sports and physical education; 8) access to specific educational information to help to ensure the health and well-being of families, including information and advice on family planning”.

${ }^{11}$ Population of PRC, 1.345.751.000; Population of Taiwan region, 23.046.177; Population of Turkey, 71.517.100. Population differences and population dynamics between those States and Special Administration Region do not allow the making of comparative analysis on population and conclude a research based on this.

${ }^{12}$ Both States and Special Administration are affected by different history, cultural background, religion, beliefs, political history and recent status. Furthermore, the economic status of China, Taiwan and Turkey exhibit significant differences.

${ }^{13}$ Whereas in Turkey, it is compulsory to obtain a Bachelor's degree in law to apply for the Bar Associations, in China, to apply for legal evaluation exam
} having a bachelor degree is enough. 
In addition, there are some similarities existing in relation to legal education, examples being:

- Both States are followers of a "Continental Legal System";

- Neither State has a completely genuine and unique legal system;

- Both States operate under the effects of international legislative documents;

- Both States aim to achieve a unified legal system.

Taking into account of all these considerations, it should be noted that although there are many difficulties and differences which may inhibit the conducting of a comprehensive and comparative study among those States, these difficulties and differences do not preclude briefly introducing the legal basis of education, right to education and legal education, for each State. Secondly, even though statistics are somewhat limited, such statistics as do exist provide the basis of an introduction to the current status of legal education in each State. The fundamental issue to be considered is that education of women is far more significant to the development of women than other rights. And having female legal professions indicates a fact to protect the rights of women in the rule of law society, in particular the equal rights.

\section{People's Republic of China}

\section{Mainland China}

\section{An Overview of the Education System in Mainland China}

At present, the majority of females in mainland China received at least primary school or junior high school education. Only $14 \%$ of females are considered as being illiterate and most of these are over 60 years of age. In addition, only small proportion of females received senior high school or college education, their numbers representing some $17 \%$. It is, therefore, fair to say that the majority of females receiving education in mainland China are only educated at primary and secondary school levels.

Observing this situation from the viewpoint of historical development, between 1931-1945, there were only approximately 780 million females who received primary school education, only $0.46 \%$ of females received higher education ${ }^{14}$ and in excess of $90 \%$ of females were illiterate during that period of time.

Due to the policy of promoting, "common primary and secondary education”, after 1949, the proportion of illiteracy was gradually reduced. In the 1980s, the policy of "nine-year compulsory education” was introduced and implemented, throughout mainland China. As a result, most of the younger generations received at least a junior high school education.

Since the rapid development of the higher education system in the 1990s, females have had more opportunity to receive higher education. For example, 23.6\% of females received higher education in the 1980s and the situation improved to $35.4 \%$ in 1995 and further improved to $45.7 \%$, in 2004 . It was also observed that, in 2004, 44.2\% of Masters' students in mainland China were female and they represented 31.4\% of Ph.D students. The aforesaid situation was a great improvement in comparison to the situation in 1995 (Gao, 2004).

\footnotetext{
${ }^{14}$ Here, "higher education" means education at college or postgraduate levels.

${ }^{15}$ These types of school provide professional training that reflects the needs of the job market, examples being, IT skills and accountancy.

${ }^{16}$ Due to the lack of information about total numbers of law colleges and students of law colleges in China, we prefer to analyze only one Law College in this study.

${ }^{17}$ Article 7 of the Constitution Law of Taiwan.

${ }^{18}$ Article 1018 I of the Civil Act.
}

The Compulsory Education Act was implemented in 1986 and it provided reasonable legal protection for young children (both males and females) to receive at least "nine-year" free education. This policy also helped to partially ease the financial pressure on some families, in particular, those in the countryside. The aforesaid was deemed to be the "double legal protecttion" which had secured the situation whereby young girls would receive an education. The "Nine-year compulsory education" policy has been implemented throughout most of mainland China and almost all young girls will have the opportunity to receive primary school education. It is, therefore, fair to state that at the elementary school stage, females are receiving the same education opportunity as males. It is, however, a fact that the proportion of male students in senior high school was still far greater than for females.

There was an exception in that female students were much more highly represented than males at the "technical high school"15, in particular in the rural areas. This was a result of the demands of the job market in rural areas. It was also note worthy that there were a number of female students (about $2 \%-3 \%$ ), who did not finish their degrees, as has been shown by recent research (Tan, 2011). The most recent development is that there are a significant amount of females participating in higher or adult higher education diploma training courses. The aforesaid training courses focus on nursing, secretarial, public relations, financial sectors, as well as tourism and IT sectors, all of which reflect the current market needs.

In summary, the current development of the modern education system in mainland China has brought better opportunities for females, in terms of receiving better higher education. The "technical high school" and "job training diploma courses" also offered training opportunities, which reflecting the job market needs, in particular, those opportunities for females. Subsequently, these circumstances provide basic preconditions for females; to be able to participate in social and economics activities, which will in turn, raise the social status of females.

\section{An Overview of Legal Education in Mainland China}

Here, we briefly summarise the legal education and statistics as regards the employment position of women in the legal field in mainland China:

1) Recently, there numbered 609 Law Colleges or Law Departments under the authority of other Colleges around mainland China ${ }^{16}$;

2) 628 Undergraduate students, with 241 male and 387 female students, at Shanghai Maritime University;

3) 447 Postgraduate students, with 163 male, 284 female students, at Shanghai Maritime University;

4) 200,000 Judges, with 44,502 of them being females, in mainland China;

5) 214,900 Prosecutors, with a little more than 30,000 being female;

6) 143,000 Lawyers, with 23,753 of them being female.

\section{Taiwan Region}

\section{An Overview of the Education System in Taiwan Region}

The principle of the "equality of males and females" was explicitly stipulated in the Constitution Law of Taiwan ${ }^{17}$. Even so, it remains a fact that this principle cannot be applied entirely throughout all the laws in Taiwan. For example, Article 1059 I of the Civil Act states that "children should be named after their father's surname". Another typical example is that if the couple operates a "joint financial management system", the husband will have the final say in any dispute ${ }^{18}$.

In accordance with a recent survey published by the Internal 
Department, Taiwan region, 33.85\% of the entire population is in receipt college or postgraduate education. $33.21 \%$ of people have received senior high school or technical high school training whereas, $15.69 \%$ of the population only received primary school education. It was also observed that the proportion of people receiving college or postgraduate education has increased by $17.86 \%$ in the past 10 years. The literacy rate for over 15 year olds was $97.6 \%$, which means that, in 100 people, there are still 2.4 people who are illiterate. The female literacy rate was $3.5 \%$ lower than for males, which was due to the fact that male literacy rate was $22.6 \%$ higher among people over 65 years of age but the rate figure was virtually equal among those under the age of 40 .

Analyzing the population structure, 6.4 million people receive college or even higher education. Among these, 3.38 million (52.75\%) are males and 3.02 million (47.25\%) are females. It was noteworthy that a higher percentage of the female population received higher education as opposed to males, among the under 35 age group. Those over 35, however, displayed the opposite situation to that of the females. This is due to the fact that in the early stages of educational development, females' education rights were significantly ignored. The gap was enormous, in particular, for those over the age of 50.

\section{An Overview of Legal Education in Taiwan Region}

Here, we briefly indicate the legal education and relevant statistics on the employment positions of women in the legal field in Taiwan region:

7) Currently, there are 45 Law Colleges providing law education, among the 145 Universities in Taiwan region;

8) Judges in Taiwan region; in total, there are 1713 Judges, 1028 of them being male and 685 of them, females (Judicial Yuan, 2009);

9) Prosecutors in Taiwan region; There are 1225 Prosecutors, with 824 of them being male and 401 of them, female (Ministry of Justice, 2009).

In relation to Taiwan region, unfortunately we have been unable to establish the details a regards lawyers and their sex ratio, however, fortunately we have been able to identify undernoted data relating to the gender ratio of law college students, this being as undernoted.

In accordance with the statistic as has been shown in Table 1, we may conclude that, in recent years, the differences in gender ratio in colleges of Taiwan region have reduced and nowadays, the difference in the gender ratio in law colleges is remarkably low. The statistics indicates that, for example, in 2008, the ratio had almost reached parity.

The current development in Taiwan region is that female legal scholars ${ }^{19}$ who received higher education abroad and now gradually have impact on the society, in particular at the political sector. This tendency will in turn encourage more female students to persuade their postgraduate study abroad. The overall outcome of this tendency is, however, subject to further observation.

\section{Turkey}

\section{An Overview of the Education System in Turkey}

Article 10 of the Constitution of the Turkish Republic explicitly prescribes the equality of males and females. In the context of Article 10, males and females have equal rights and

\footnotetext{
${ }^{19}$ For example, Ex-Vice Taiwan Region leader Miss Lu and the current regional leader candidate Miss Tsai.
}

Table 1.

The gender ratio of law college students in Taiwan (Ministry of Education, 2009).

\begin{tabular}{ccc}
\hline \multicolumn{2}{c}{ Sex Ratio } \\
\hline Year & Male & Female \\
\hline 1998 & $56.86 \%$ & $43.14 \%$ \\
1999 & $57.15 \%$ & $42.85 \%$ \\
2000 & $55.57 \%$ & $44.43 \%$ \\
2001 & $55.22 \%$ & $44.78 \%$ \\
2002 & $54.12 \%$ & $45.88 \%$ \\
2003 & $53.41 \%$ & $46.59 \%$ \\
2004 & $52.50 \%$ & $47.50 \%$ \\
2005 & $51.81 \%$ & $48.19 \%$ \\
2006 & $51.40 \%$ & $48.60 \%$ \\
2007 & $51.00 \%$ & $49.00 \%$ \\
2008 & $50.53 \%$ & $49.47 \%$ \\
\hline
\end{tabular}

the State undertakes the responsibility of achieving this equality. With regard to second part of the Constitution, according to the Fundamental Rights, Article 27, everyone has the right to learn, teach and to introduce and research science and art. Consistent with the Articles 10 and 27, 42 stipulates that none can be divested of the education right.

In accordance with Article 42, primary education is compulsory for both males and females and is free of charge in the State schools. The State undertakes the responsibility to provide scholarships and other kinds of appropriate measures to assist students from financially disadvantaged backgrounds. In addition to the framework prescribed in the Constitution, the National Education Code, the Turkish Civil Code, the Population Service Code, the Turkish Criminal Code, the Criminal Proceeding Code, the Code on Unification of Education, the Code on Protection of Family and the Labour Code, all stipulate Articles relating to right to education and the principle of equality between males and females.

The compulsory elementary education in Turkey provides for 8 years of education for every citizen and is free of charge in the State schools, under the terms of the National Education Code and the Code on the Unification of Education. The Constitution and relevant Codes prescribe that States undertake the responsibility to provide all proper measures to achieve elementary education, this being without charge in the State schools. These regulations and State policy help to partly ease the financial pressures on some families, in particular those in rural areas and particularly those in the eastern and south-eastern parts of Turkey.

In accordance with a recent survey published by the Turkish Statistics Organization, the literacy rate for those over 15 years old age is $91.760 \%$. The illiteracy rate of males above 15 years of age is, however, 3.687\% (among all males over 15 years of age), the illiteracy rate for females in the same age group is 14.749\% (Ministry of Education, 2009). $7.275 \%$ of people who exceed 15 years of age receive college or other higher education; $18.943 \%$ of these receive high school or technical high school education; $16.103 \%$ receive mid-school education and $34.352 \%$ receive only primary school education (Ministry of Education, 2009). Analyzing the population structure and statistics, the literacy rate in Turkey is significantly lower than in mainland China and Taiwan region. The statistics for Turkey indicate that the literacy rate of females has increased rapidly since the foundation of Turkish Republic in 1923 but the rate of 
literacy for females still does not reach the same rates as in the developed countries and still needs further development, in order to achieve $100 \%$ literacy in the State.

\section{An Overview of Legal Education in Turkey}

Here, we briefly indicate the legal education and statistics as regards the employment positions of women in the legal field in the Turkish Republic.

Currently, there are 48 Law College (22 of them are State owned and 26 of them are Private University Law Colleges) providing legal education, among the 139 Universities (The Council of Higher Education, 2009) (94 of them are State owned and 45 of them are Private Universities) in the country. Education in Law Colleges in Turkey is based on classical the lecturing methodology and in particular, follows German education methods. The legal education system is based on one way presentations, meaning that Professors deliver presentations on theatrical issues and Research Assistants deliver presentations on practical issues. Students' interactive participation in classes is limited, with the practical issues being delivered by Research Assistants. Unfortunately, we are unable to elicit any statistics as regards numbers of Law College students in Turkey and the gender ratio thereof. Even although males and females have apparent equality and the same opportunity to enter law colleges, the gender ratio of those working as legal professionals in Turkey indicates that males still playing the dominant role.

With regard to Table 2 (Turkish Statistical Institute, 2009), whereas the percentage of female judges from the total in Turkey was $29.334 \%$ in 1997 , the percentage in 2007 was $28.200 \%$, being and slightly less than in 1997.

With regard to Table 3 (Turkish Statistical Institute, 2009), the percentage of female public prosecutors in the Turkish Republic in 1997 was 3.62\%, whereas, by 2007 the figure had risen to $5.625 \%$. The gender ratio of female prosecutors in Turkey is thus, significantly less than in mainland China or Taiwan region.

With regard to Table 4 (Turkish Statistical Institute, 2009), the percentage of female lawyers in Turkey, as at 31st December 2008, was $36.832 \%$ of the total. This statistic indicates that female legal professionals prefer to participate as a lawyer, rather than as a judge or public prosecutor in Turkey ${ }^{20}$.

\section{Discussions and Recommendations}

Even although this study does not aim to focus on statistical analysis, when considering the tables above, it may be concluded that Taiwan region has the highest literacy rate and highest rate for college or above college level graduation. Compared to mainland China and Taiwan region, the literacy rate in Turkey is significantly lower and needs to take further steps and measures to improve the country's literacy and education situation.

The gender ratio for primary school education in mainland China, Taiwan region and Turkey, is almost the same. Despite the gender ratio of females being similar for primary education, the ratio of females in higher education is markedly lower than for males in both States.

In addition to the general problems of higher education opportunities for females, legal education and the legal professional field have its own unique difficulties, such as:

\footnotetext{
${ }^{20}$ Unfortunately we are unable to reach the sex ratio of female public notaries and female law college professors and lecturers in Turkey and in order to this we are unable to count those issues in this study.
}

Table 2.

The gender ratio of Judges in the Turkish Republic.

\begin{tabular}{lccc}
\hline & & Judge & \\
\hline Years & Female & Male & Total \\
\hline 1999 & 1554 & 3745 & 5299 \\
2000 & 2599 & 3973 & 6572 \\
2001 & 1674 & 4225 & 5899 \\
2002 & 1725 & 4388 & 6113 \\
2003 & 1744 & 4473 & 6217 \\
2004 & 1687 & 4288 & 5975 \\
2005 & 1692 & 4284 & 5976 \\
2006 & 1722 & 4461 & 6183 \\
2007 & 1995 & 5081 & 7076 \\
\hline
\end{tabular}

Table 3.

The gender ratio of Prosecutors in the Turkish Republic.

\begin{tabular}{cccc}
\hline & & \multicolumn{2}{c}{ Prosecutors } \\
\hline Year & Female & Male & Total \\
\hline 1999 & 100 & 2676 & 2776 \\
2000 & 100 & 2776 & 2876 \\
2001 & 111 & 2938 & 3049 \\
2002 & 122 & 3114 & 3236 \\
2003 & 130 & 3169 & 3299 \\
2004 & 139 & 3088 & 3227 \\
2005 & 130 & 3039 & 3169 \\
2006 & 172 & 3297 & 3469 \\
2007 & 215 & 3607 & 3822 \\
\hline
\end{tabular}

Table 4.

The gender ratio of Lawyers with relating to the five largest Bar Associations and the total number in Turkey.

\begin{tabular}{cccc}
\hline & \multicolumn{3}{c}{ Lawyers } \\
\hline Place of Bar & Female & Male & Total \\
\hline Adana & 502 & 952 & 1454 \\
Ankara & 3551 & 5403 & 8954 \\
Antalya & 694 & 1358 & 2052 \\
Bursa & 508 & 1111 & 1619 \\
Istanbul & 9210 & 14,674 & 238,884 \\
Izmir & 2076 & 3415 & 5491 \\
Total in Turkey & 23,378 & 40,109 & 63,487 \\
\hline
\end{tabular}

- Enforced education period;

- Negative public opinion as regards legal professionals;

- Enforced and stressful working conditions;

- Physical and mental harassments of female legal professsionals.

Taking into account these considerations, we would recommend the undernoted aims and objectives for both States and Taiwan region:

- Aim to achieve $100 \%$ literacy in 15 - 20 years and to take all appropriate measures to secure this;

- Positively encourage female students to enter the university exams;

- Create a better law education and legal professional field 
for everyone;

- Avoid all types of harassments against female legal professionals.

Based on the above discussion, we cannot reach a conclusion that more female legal professions will enhance the protection of women's rights. What we can conclude is that there is a general intention in both States and region to provide equal education opportunity for female. Female students are more likely to choose "law" as a subject of their higher education, however, the current figures indicate that male is still dominating legal professions. What is important is that equal opportunity should be guaranteed no matter education or latter get into the job market.

\section{Acknowledgements}

The field work for this research was supported by the "Independent Innovation Foundation of Shandong University”. Granting number: IFW10053.

\section{References}

Gao, X. (2004). Chinese women's education in women's eyes. Jiangxi Institute of Education, 6, 24.

Huang, Q. L. (2006). Comparison of education in the rural areas between China and India. Master Degree Thesis, Jilin: Northeast Normal University.
Judicial Yuan (Taiwan) (2009). The employer's number belonging to the Judicial Yuan. URL (last checked 30 November 2009) http://www.judicial.gov.tw/juds/report/st-1.htm

Ministry of Education (Taiwan) (2009). Gender statistics indicators. URL (last checked 30 November 2009)

http://www.edu.tw/statistics/content.aspx?site_content_sn=8168

Ministry of Education (Turkey) (2009). The population of completed education level and sex. URL (last checked 30 November 2009) http://report.tuik.gov.tr/reports/rwservlet?adnksdb2=\&report=turkiye _cinsiyet_yas_egitim_top.RDF\&p_xkod=egitim_kod\&p_yas=15\&p_ yil=2008\&p_dil=1\&desformat=pdf\&ENVID=adnksdb2Env

Ministry of Education (Turkey) (2009). The population of literacy status and sex. URL (last checked 30 November 2009) http://report.tuik.gov.tr/reports/rwservlet?adnksdb2=\&report=turkiye cinsiyet_yas_egitim_top.RDF\&p_xkod=okuryazar_kod\&p_yas $=15$ \&p_yil=2008\&p_dil=1\&desformat=pdf\&ENVID=adnksdb2Env

Ministry of Justice (Taiwan) (2009). The number of prosecutors. URL (last checked 30 November 2009) http://www.moj.gov.tw/site/moj/public/MMO/moj/stat/gender/prost. pdf

Tan, L. (2011). China's gender equality and women's development report 1995-2005. URL (last checked 21 July 2011) http://en.wsic.ac.cn/researchproduction/ 1376.htm

The Council of Higher Education (Turkey) (2009). The statistics of state universities. URL (last checked 30 November 2009) http://www.yok.gov.tr/content/view/531/ lang,tr/

Turkish Statistical Institute (Turkey) (2009). Dynamic query databases and statistical tables. URL (last checked 30 November 2009) http://www.tuik.gov.tr/VeriBilgi.do?tb_id=41\&ust_id=11 